\title{
Pulmonary tumor thrombotic microangiopathy of patient with both hepatocellular carcinoma and gastric signet-ring cell carcinoma: a case report and review of literature
}

\author{
Lulei Shen $^{1 \#}$, Li Yang ${ }^{1 \#}$, Hanshui Jiang ${ }^{1}$, Ting Mo ${ }^{1}$, Mengdi Fan ${ }^{2}$ \\ ${ }^{1}$ Department of Respiratory Diseases, Shulan (Hangzhou) Hospital Affiliated to Zhejiang Shuren University Shulan International Medical College, \\ Hangzhou, China; ${ }^{2}$ Department of Endocrinology, Shulan (Hangzhou) Hospital Affiliated to Zhejiang Shuren University Shulan International \\ Medical College, Hangzhou, China \\ "These authors contributed equally to this work. \\ Correspondence to: Hanshui Jiang. Department of Respiratory Diseases, Shulan (Hangzhou) Hospital Affiliated to Zhejiang Shuren University Shulan \\ International Medical College, Hangzhou 310000, China. Email: jianghanshui@hotmail.com.
}

\begin{abstract}
Pulmonary tumor thrombotic microangiopathy (PTTM) is a rare cancer-related complication characterized by intimal proliferation in the pulmonary small arteries with or without tumor emboli, which can be fatal due to progressive pulmonary hypertension (PH). And PTTM is hard to be confirmed during lifetime; hence, it is vital to pay more attention to high-risk PTTM, which may progress quickly. PTTM patients have an extremely poor prognosis. Here, we have reported a case of a patient with both hepatocellular carcinoma (HCC) and gastric signet-ring cell carcinoma who presented with dyspnea and died rapidly and was diagnosed with suspected PTTM. In addition, we have reviewed some related literature. This patient showed a poorer prognosis, with a survival time of only 3 days after oxygen supplementation (very poor compared to the average level of PTTM patients caused by gastric carcinoma only, which was 18 days according to our summary). Besides, respiratory discomfort is the main symptom of PTTM. Abnormal pulmonary imaging was reported with the appearance of septal thickening, ground-glass opacities, small nodules, pleural effusion, and a tree-in-bud pattern in PTTM patients. No effective therapeutic options have been established for PTTM. PTTM should be considered in patients with cancer who progress to rapid respiratory failure and $\mathrm{PH}$, especially in patients with multiple tumors whose condition is more likely to deteriorate quickly.
\end{abstract}

Keywords: Pulmonary tumor thrombotic microangiopathy (PTTM); hepatocellular carcinoma (HCC); gastric signet-ring cell carcinoma; respiratory failure; case report

Submitted Oct 20, 2020. Accepted for publication Mar 05, 2021.

doi: $10.21037 /$ tcr-20-3107

View this article at: http://dx.doi.org/10.21037/tcr-20-3107

\section{Introduction}

Pulmonary tumor thrombotic microangiopathy (PTTM), defined by von Harvey et al. (1) in 1990, is a rare pulmonary manifestation of malignancy. Tumor embolism, multiple microthrombi, and intimal myofibroblast proliferation in the pulmonary arteries and arterioles are among its histopathological characteristics $(1,2)$. It is most commonly associated with gastric adenocarcinoma, but it has also been described in other carcinomas (1). The pathogenesis begins with the formation of microscopic tumor cell emboli that induce local activation of coagulation and fibrocellular intimal proliferation. Eventually, stenosis and/ or occlusion occur along with an increase in pulmonary

^ ORCID: 0000-0001-6476-282X. 


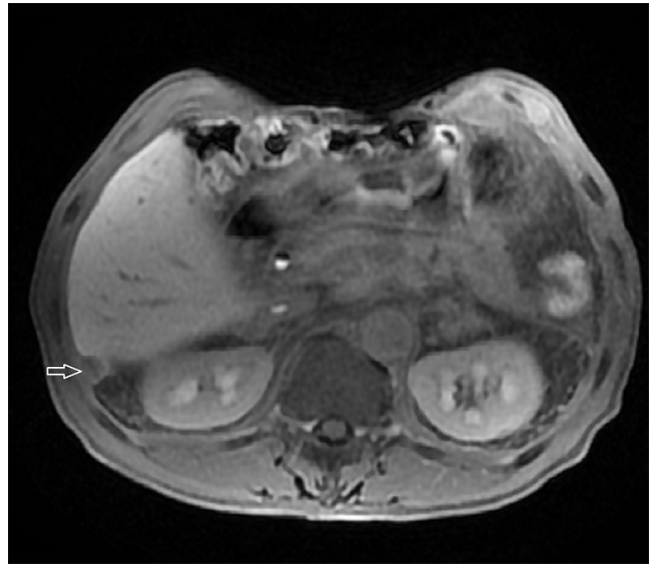

Figure 1 Contrast magnetic resonance of a sub-peritoneal nodule at the right posterior margin of the liver.

vascular resistance that results in $\mathrm{PH}$, hemolytic anemia, and disseminated intravascular coagulation (DIC). It is associated with the development of clinical signs of pulmonary hypertension $(\mathrm{PH})$ that result in acute or subacute cor pulmonale and subacute respiratory failure (1). Computed tomography (CT)-guided lung puncture biopsy or bronchoscopy lung biopsy is the gold standard for the diagnosis of PTTM. Elevated concentrations of D-dimer or fibrin degradation products, $\mathrm{PH}$ measured by cardiac ultrasound or right heart catheterization of the pulmonary artery, and distal perfusion abnormalities of pulmonary perfusion imaging may help clinicians establish an early diagnosis of PTTM (3). Further, no arterial embolization from CT pulmonary angiography (CTPA) is necessary to diagnose PTTM. Therefore, for patients with cancer manifesting with severe $\mathrm{PH}$ but no arterial embolization from CTPA, CT-guided lung puncture biopsy or bronchoscopy lung biopsy is recommended to rule out the possibility of a missed diagnosis of PTTM. The condition of our patient with both hepatocellular carcinoma (HCC) and gastric signet-ring cell carcinoma who developed PTTM deteriorated faster than that of patients with gastric carcinoma only. Furthermore, we have reviewed 19 reported cases (4-19). We present the following article in accordance with the CARE reporting checklist (available at http://dx.doi.org/10.21037/tcr-20-3107).

\section{Case presentation}

A 62-year-old Chinese man was diagnosed with HCC and liver cirrhosis caused by hepatitis B in 2011. He had undergone radiofrequency ablation. In December 2018, he visited our hospital due to HCC recurrence and was treated with transhepatic arterial chemotherapy and embolization (TACE). However, he developed hepatic encephalopathy, and liver transplantation was performed in February 2019. Postoperative pathology revealed the following: middle caudate lobe differentiated HCC, nodular type, 1-cm diameter, liver capsule invasion, microvascular invasion $(\mathrm{MVI})$ grade $=\mathrm{M} 0$, and nerve invasion $(-)$. A necrotic nodule measuring $4 \mathrm{~cm}$ in diameter was observed in the right liver. Subsequently, he was regularly treated with tegafur, gimeracil, and oteracil potassium; his condition remained stable.

In March 2020, he had a follow-up visit. His hepatobiliary contrast magnetic resonance imaging showed a sub-peritoneal nodule at the right posterior margin of the liver (Figure 1). Moreover, positron emission tomography (PET) showed no increased fluorodeoxyglucose (FDG) metabolism in the peritoneal nodules at the right posterior edge of the liver, and part of the small intestine's FDG metabolism increased, and endoscopy was recommended (Figure 2). A biopsy of the sub-peritoneal nodules at the posterior margin of the liver showed HCC (Figure 3), and radiofrequency ablation was performed. The patient was treated with chemotherapy (oxaliplatin, calcium folinate, and fluorouracil). He had a gastroscope, which unfortunately showed poorly differentiated adenocarcinoma (gastric signet-ring cell carcinoma) (Figure 4).

Before chemotherapy for gastric signet-ring cell carcinoma, he developed sudden onset of severe dyspnea and hemoptysis on May 16, 2020. Blood gas showed $\mathrm{pH}$ of 7.44, oxygen saturation $\left(\mathrm{SpO}_{2}\right)$ of $80.9 \%$, oxygen tension of $44 \mathrm{mmHg}$, carbon dioxide tension of $30.9 \mathrm{mmHg}$, bicarbonate level of $22.4 \mathrm{mmol} / \mathrm{L}$, and base excess (BE) of $-1.8 \mathrm{mmol} / \mathrm{L}$, without oxygen (Table 1). Coagulation showed that the D-dimer level was significantly increased to $38,720 \mu \mathrm{g} / \mathrm{L}$ (159 times the normal value) and fibrinogen was decreased to $1.72 \mathrm{~g} / \mathrm{L}$ (72\% of normal) with a prothrombin time activity of $13.7 \mathrm{~s}$ (1.1 times the normal value), suggestive of DIC. In Table 1, the blood platelet count decreased to $75 \times 10^{9} / \mathrm{L}(60 \%$ of normal), and the white blood cell count was normal with a C-reactive protein level of $96 \mathrm{mg} / \mathrm{L}$ (9.6 times the normal value) (Table 1). Biochemistry was generally normal with low serum albumin $(32.8 \mathrm{~g} / \mathrm{L} ; 82 \%$ of normal) (Table 1$)$.

Chest radiography showed a new frosted glass-like shadow on May 16, 2020, compared to the image on May 11, 2020 (Figure 5), while CTPA showed no arterial 


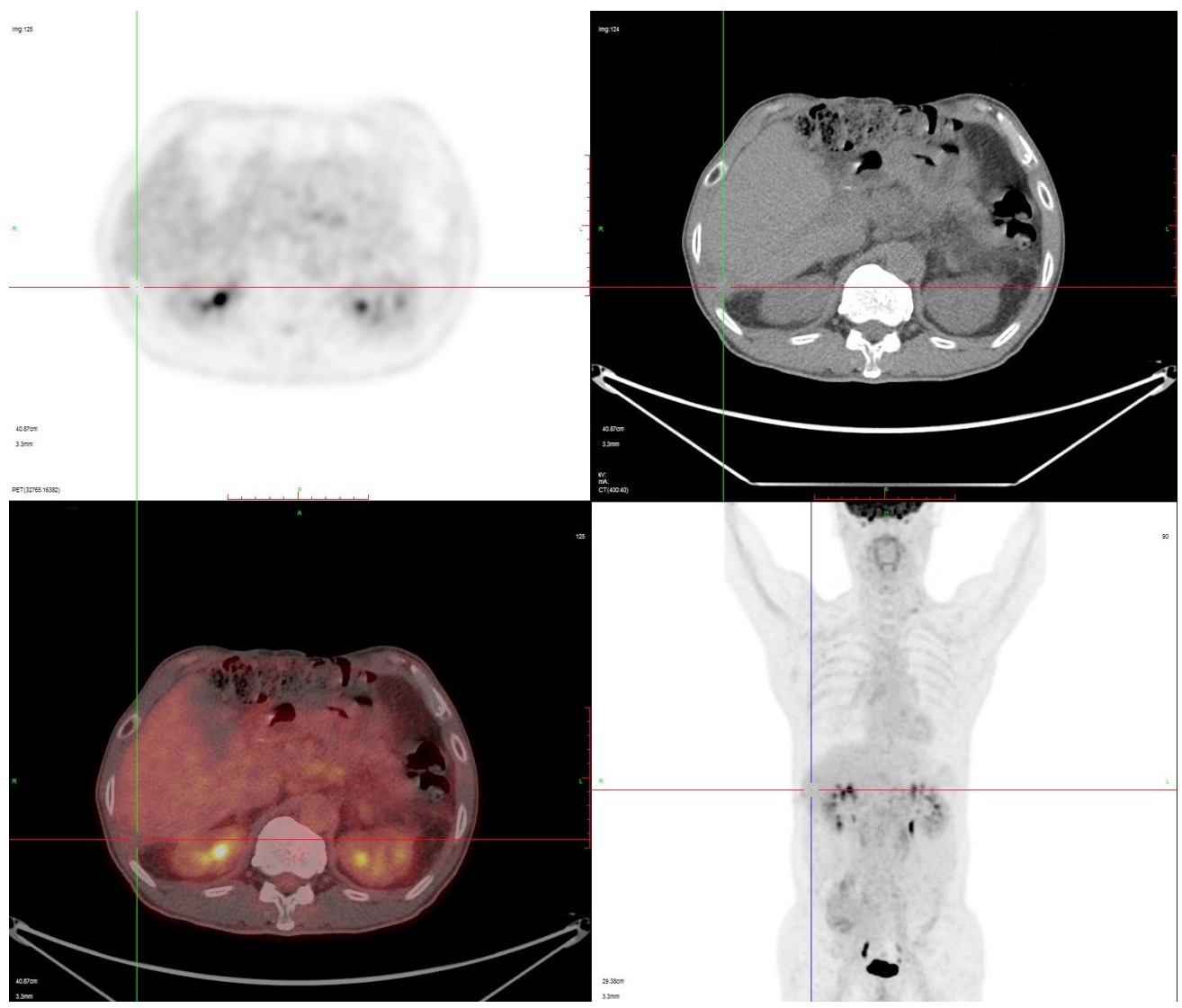

Figure 2 Positron emission tomography (PET) showed no activity was found in the peritoneal nodules at the right posterior edge of the liver after liver transplantation.
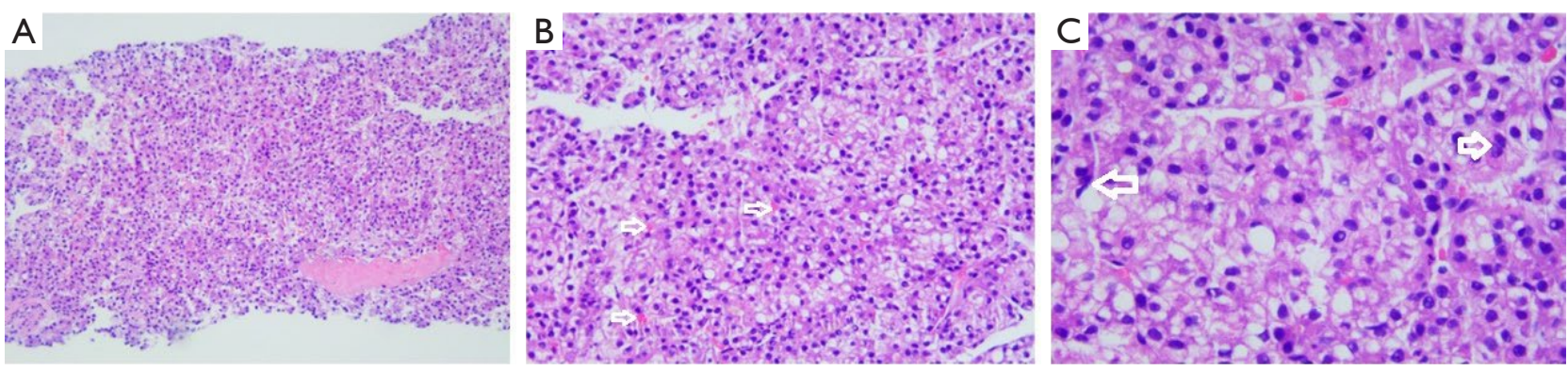

Figure 3 Pathology of nodule at the right posterior margin of the liver showed HCC. Immunohistochemical analysis: hepatocyte(+), AFP(-), glypican-3(+), GS(-), CA199(-), CDX2(-), CK20(-), SATB2(-), CEA(-), villin(-), CK7(-). (A) The hepatic lobular structure disappeared, the hepatic plate was significantly thickened, and the tumor cells were arranged in trabeculae (hematoxylin-eosin staining, 100×). (B) A disordered arrangement of tumor cells with increased cell density and abundant sinusoids (arrows indicate sinusoids; hematoxylin-eosin staining, 200×). (C) Tumor cells with atypia have significantly increased nucleoplasma ratio, and some of the tumor cells have steatosis (arrows show tumor cells with atypia; hematoxylin-eosin staining, 400x). HCC, hepatocellular carcinoma. 

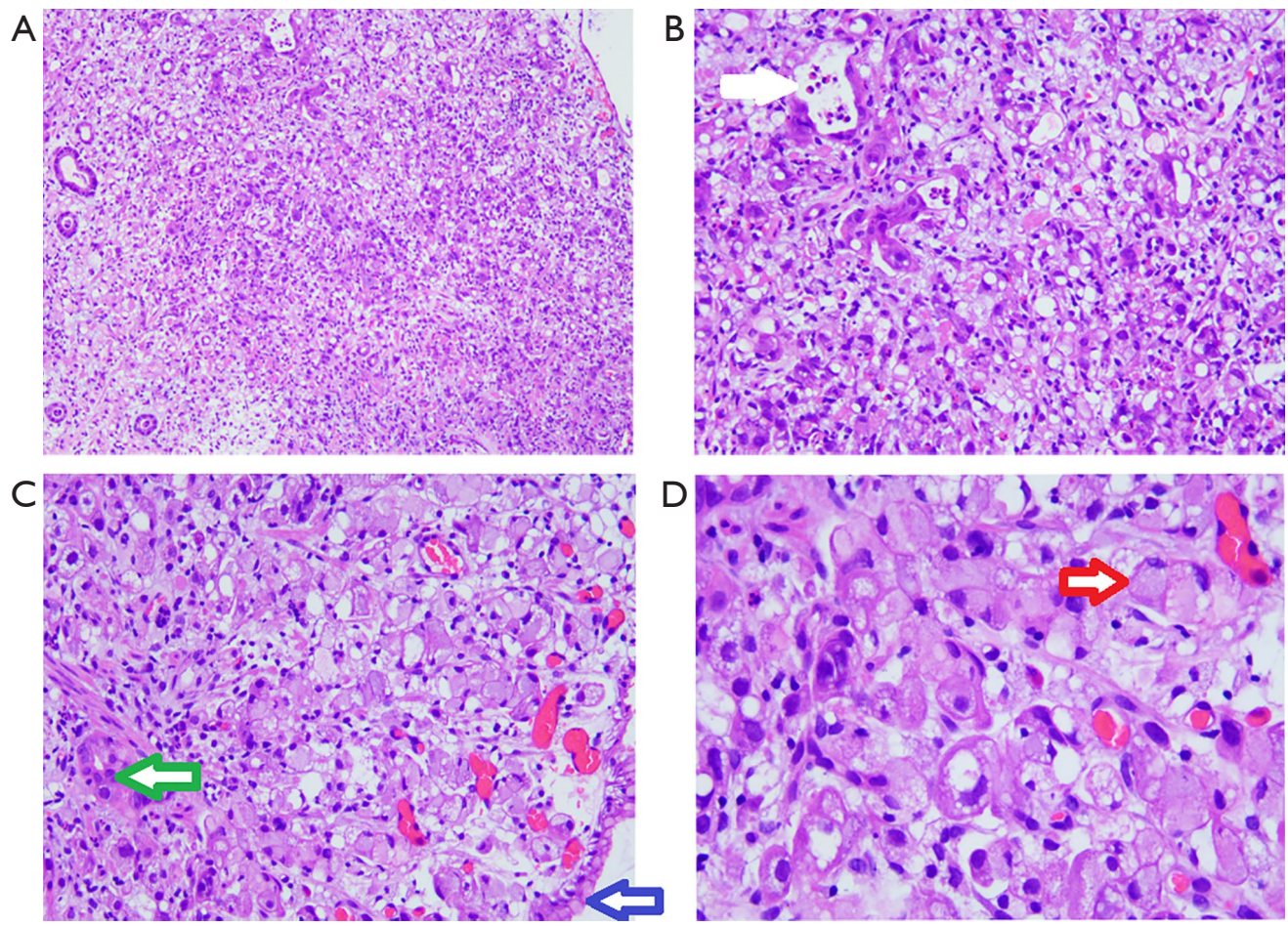

Figure 4 Pathology of stomach showed poorly differentiated adenocarcinoma (gastric signet-ring cell carcinoma). (A) Tumor cells, most of them are patchy and diffusely distributed, with only a few tumor cells forming adenoid structures (hematoxylin-eosin staining, 100x). (B) The neoplastic cells are clearly abnormal, with necrotic exudates in the irregular abortive glands (arrows show necrotic exudates; hematoxylineosin staining, 200x). (C) The normal submucosal stroma of the stomach is filled with diffuse tumor cells, and some smooth muscle tissue is being eroded by the tumor (the blue arrow shows normal gastric mucosa, the green arrow shows smooth muscle; hematoxylin-eosin staining, 200x). (D) The tumor cells have a rich cytoplasm filled with mucus, which squeezes the nucleus to the side of the cell, like a "signet ring" (the red arrow shows a signet ring tumor; hematoxylin-eosin staining, 400×).

embolization (Figure 6). Cardiac ultrasound showed severe tricuspid regurgitation, which suggested high pulmonary arterial hypertension. Anticoagulant therapy and antibiotics were administered, but his condition worsened, and he died 3 days (May 18, 2020) after oxygen supplementation.

All procedures performed in studies involving human participants were in accordance with the ethical standards of the institutional and/or national research committee(s) and with the Helsinki Declaration (as revised in 2013). Written informed consent was obtained from the patient.

\section{Final diagnosis}

The diagnosis was PTTM, likely caused by tumor cell embolization of the HCC and gastric signet-ring cell carcinoma after multidisciplinary expert discussion, which led to rapid respiratory failure.

\section{Treatment}

Since PTTM was considered, we used enoxaparin $40 \mathrm{mg}$ subcutaneous injection once a day, oxygen therapy, and cephalosporin for possible secondary infection. We administered $40 \mathrm{mg}$ methylprednisolone intravenous injection once a day to reduce the inflammatory reaction in the lung.

\section{Outcome and follow-up}

The patient's condition worsened rapidly and died 3 days after oxygen supplementation.

\section{Discussion}

PTTM is a rare form of pulmonary arterial tumor embolism. Fibrocellular intimal proliferation of the small 
Table 1 Laboratory examination

\begin{tabular}{|c|c|}
\hline Examination & Results \\
\hline \multicolumn{2}{|l|}{ Hematology } \\
\hline WBC & $7.2 \times 10^{9} / \mathrm{L}$ \\
\hline Neutro & $77.8 \%$ \\
\hline Lymp & $5.7 \%$ \\
\hline Eos. & $1.8 \%$ \\
\hline Bas. & $1.0 \%$ \\
\hline Mon. & $13.7 \%$ \\
\hline $\mathrm{RBC}$ & $3.94 \times 10^{12} / \mathrm{L}$ \\
\hline $\mathrm{Hb}$ & $121 \mathrm{~g} / \mathrm{L}$ \\
\hline Hct & $35 \%$ \\
\hline Plt & $75 \times 10^{9} / \mathrm{L}$ \\
\hline \multicolumn{2}{|l|}{ Coagulation } \\
\hline PT & $13.7 \mathrm{~s}$ \\
\hline INR & 1.1 \\
\hline APTT & $36 s$ \\
\hline Fibrinogen & $1.72 \mathrm{~g} / \mathrm{L}$ \\
\hline D-dimer & $38,720 \mu \mathrm{g} / \mathrm{L}$ \\
\hline \multicolumn{2}{|l|}{ Biochemistry } \\
\hline TP & $58.6 \mathrm{~g} / \mathrm{L}$ \\
\hline Alb & $32.8 \mathrm{~g} / \mathrm{L}$ \\
\hline $\mathrm{Cr}$ & $76 \mu \mathrm{mol} / \mathrm{L}$ \\
\hline T-Bil & $12 \mu \mathrm{mol} / \mathrm{L}$ \\
\hline D-Bil & $5 \mu \mathrm{mol} / \mathrm{L}$ \\
\hline AST & $25 \mathrm{U} / \mathrm{L}$ \\
\hline ALT & $10 \mathrm{U} / \mathrm{L}$ \\
\hline ALP & $416 \mathrm{U} / \mathrm{L}$ \\
\hline$\gamma$-GTP & $16 \mathrm{U} / \mathrm{L}$ \\
\hline ChE & $5,688 \mathrm{U} / \mathrm{L}$ \\
\hline $\mathrm{Na}$ & $142 \mathrm{mmol} / \mathrm{L}$ \\
\hline $\mathrm{K}$ & $4.52 \mathrm{mmol} / \mathrm{L}$ \\
\hline $\mathrm{Cl}$ & $105 \mathrm{mmol} / \mathrm{L}$ \\
\hline$P$ & $0.62 \mathrm{mmol} / \mathrm{L}$ \\
\hline $\mathrm{Ca}$ & $2.21 \mathrm{mmol} / \mathrm{L}$ \\
\hline CRP & 96 mg/L \\
\hline TG & $1.16 \mathrm{mmol} / \mathrm{L}$ \\
\hline HDL-C & $0.65 \mathrm{mmol} / \mathrm{L}$ \\
\hline LDL-C & $3.6 \mathrm{mmol} / \mathrm{L}$ \\
\hline
\end{tabular}

Table 1 (continued)
Table 1 (continued)

\begin{tabular}{|c|c|}
\hline Examination & Results \\
\hline \multicolumn{2}{|l|}{ Marker } \\
\hline HBsAg & - \\
\hline Anti-HBs & + \\
\hline Anti-HBc & + \\
\hline Anti-HCV & - \\
\hline AFP & $2.0 \mathrm{ng} / \mathrm{mL}$ \\
\hline CEA & $7.6 \mathrm{ng} / \mathrm{mL}$ \\
\hline CA125 & $26.6 \mathrm{U} / \mathrm{mL}$ \\
\hline CA199 & $878.9 \mathrm{U} / \mathrm{mL}$ \\
\hline Fer & $7.3 \mathrm{ng} / \mathrm{mL}$ \\
\hline Blood gas & $2020.5 .16 \mathrm{no} \mathrm{O}_{2}$ \\
\hline $\mathrm{SpO}_{2}$ & $80.9 \%$ \\
\hline $\mathrm{pH}$ & 7.44 \\
\hline $\mathrm{pCO}_{2}$ & $30.9 \mathrm{mmHg}$ \\
\hline $\mathrm{pO}_{2}$ & $44 \mathrm{mmHg}$ \\
\hline $\mathrm{HCO}_{3}$ & $20.7 \mathrm{mmol} / \mathrm{L}$ \\
\hline $\mathrm{BE}$ & $-1.8 \mathrm{mmol} / \mathrm{L}$ \\
\hline
\end{tabular}

WBC, white blood cell; AFP, $\alpha$-fetoprotein; Alb, albumin; ALP, alkaline phosphatase; ALT, glutamic-pyruvic transaminase; APTT, activated partial thromboplastin time; AST, glutamic oxalacetic transaminase; Bas., basophil; BE, base excess; CA125, cancer antigen 125; CA199, cancer antigen 199; CEA, carcinoembryonic antigen; ChE, cholinesterase; Cr, creatinine; CRP, C-reactive protein; D-Bil, direct bilirubin; Eos., eosinophil; Fer, ferritin; $\mathrm{Hb}$, hemoglobin; HBsAg, hepatitis B surface antigen; HCV, hepatitis C virus; Hct, hematocrit; HDL-C, highdensity lipoprotein cholesterol; INR, international normalized ratio; LDL-C, low-density lipoprotein cholesterol; Lymp, lymphocyte; Mon., monocyte; Neutro, neutrophil; PIt, platelet; $\mathrm{PT}$, prothrombin time; $\mathrm{RBC}$, red blood cell; $\mathrm{SpO}_{2}$, percutaneous oxygen saturation; T-Bil, total bilirubin; TG, triglyceride; TP, total protein; $\gamma$-GTP, $\gamma$-glutamyl transpeptidase.

pulmonary arteries and arterioles in patients with metastatic carcinoma is among its histological characteristics and is associated with the development of clinical signs of $\mathrm{PH}$ that result in acute or subacute cor pulmonale and subacute respiratory failure (1).

In a report by Uruga et al. (3), who surveyed the findings of 2,215 consecutive autopsy cases of carcinoma, 30 patients (1.4\%) were diagnosed with PTTM for sure. The most common symptom was progressive dyspnea. Hypercoagulability of blood was observed in all measured cases $(n=21)$. The chest CT findings $(n=6)$ included small 

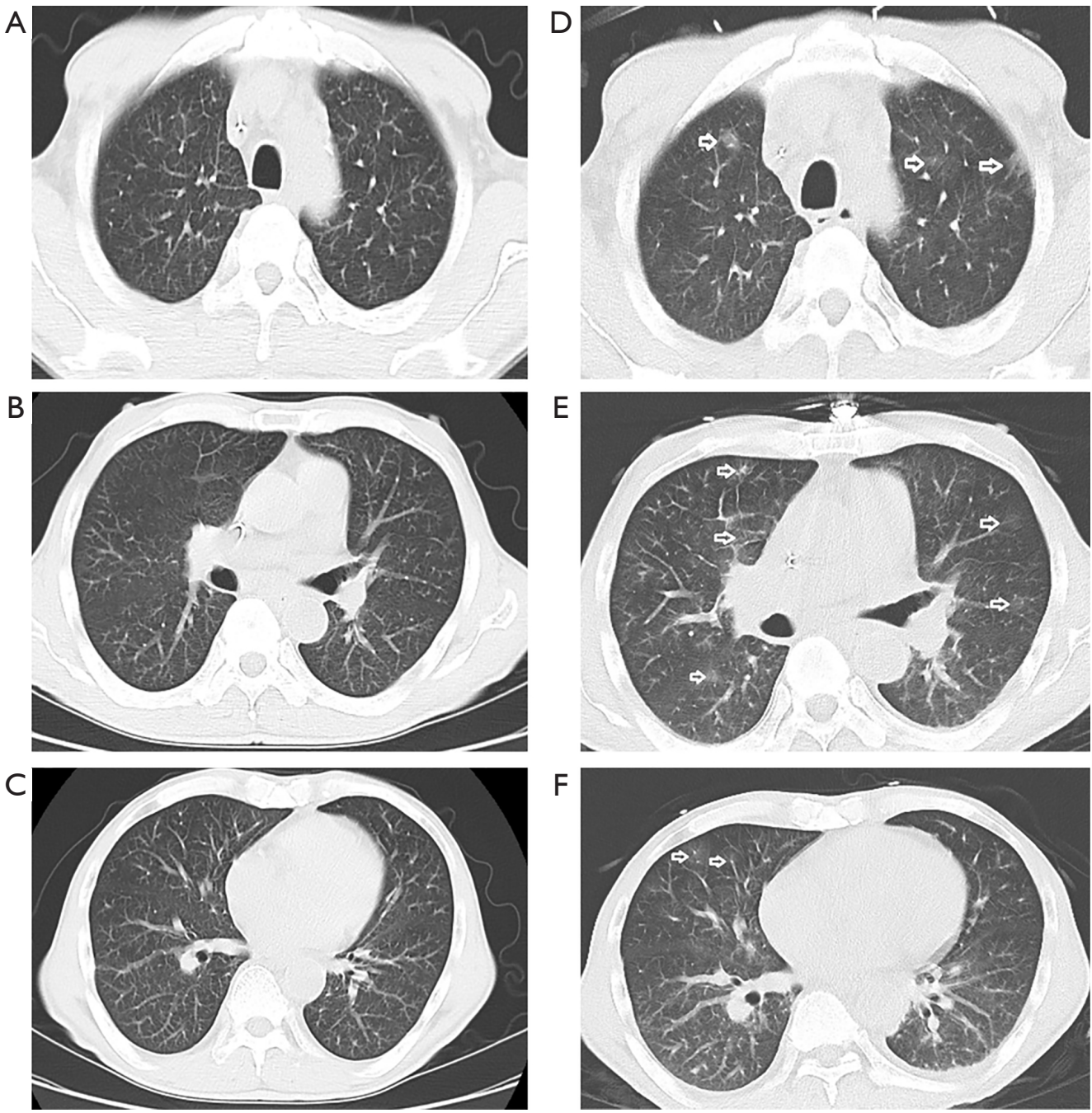

Figure 5 Chest computed tomography (CT) on May 11, 2020 and chest CT on May 18, 2020.
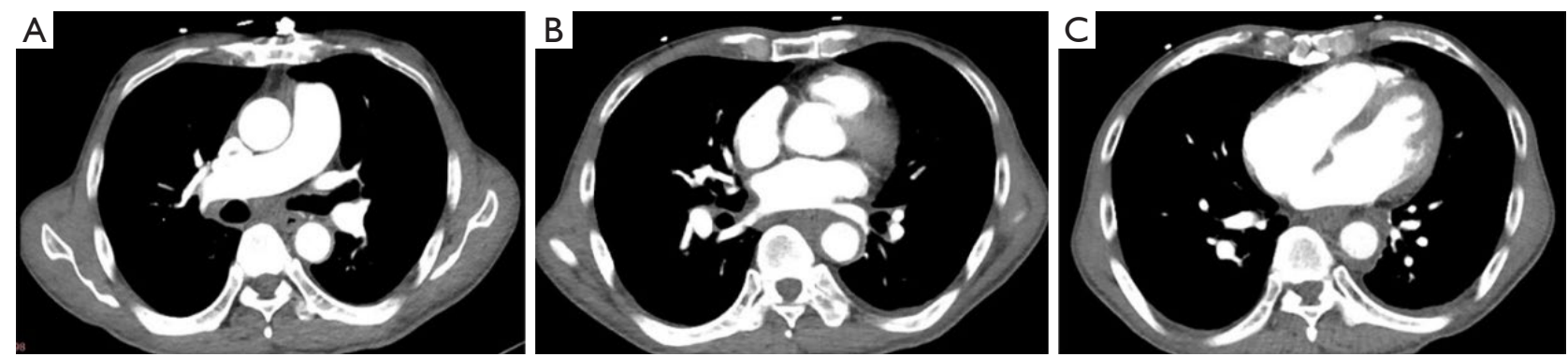

Figure 6 CTPA showed no obvious arterial embolization on May 16, 2020. CTPA, computed tomography pulmonary angiography.

nodules, ground-glass opacity, a tree-in-bud appearance and consolidation. The median survival time was nine days after the initiation of oxygen supplementation. The most common original site was the stomach $(\mathrm{n}=18 ; 60 \%)$, and the most common pathological type was adenocarcinoma (28/30, 93.3\%). PTTM caused by multiple tumors, such 
Table 2 Summary of the cases reported (PTTM gastric carcinoma related)

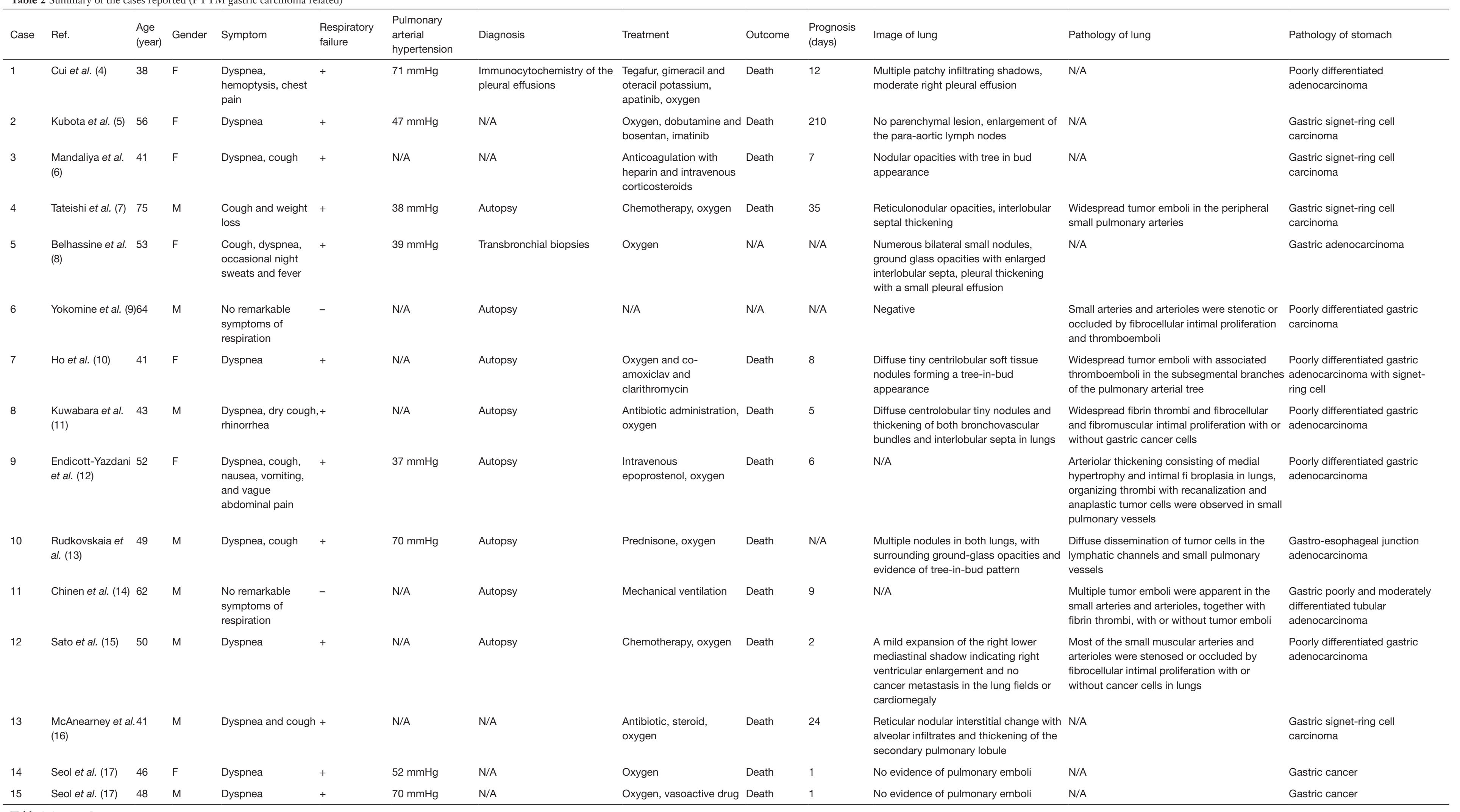




\begin{tabular}{|c|c|c|c|c|c|c|c|c|c|c|c|c|c|}
\hline Case & Ref. & $\begin{array}{l}\text { Age } \\
\text { (year) }\end{array}$ & Gender & Symptom & $\begin{array}{l}\text { Respiratory } \\
\text { failure }\end{array}$ & $\begin{array}{l}\text { Pulmonary } \\
\text { arterial } \\
\text { hypertension }\end{array}$ & Diagnosis & Treatment & Outcome & $\begin{array}{l}\text { Prognosis } \\
\text { (days) }\end{array}$ & Image of lung & Pathology of lung & Pathology of stomach \\
\hline 16 & Keenan et al. (18) & 40 & M & $\begin{array}{l}\text { Dyspnea, cough, } \\
\text { weight loss, chest } \\
\text { pain }\end{array}$ & + & $60 \mathrm{mmHg}$ & Autopsy & $\begin{array}{l}\text { Oxygen, anticoagulation } \\
\text { with heparin }\end{array}$ & Death & 11 & No evidence of pulmonary emboli & $\begin{array}{l}\text { Intimal fibrosis of the arteries, focal fresh } \\
\text { emboli of fibrin mixed with tumor cells and } \\
\text { areas of recanalization in lungs }\end{array}$ & $\begin{array}{l}\text { Poorly differentiated gastric } \\
\text { adenocarcinoma }\end{array}$ \\
\hline 17 & Gainza et al. (19) & 36 & M & $\begin{array}{l}\text { Weakness, dark } \\
\text { urine }\end{array}$ & + & N/A & Autopsy & $\begin{array}{l}\text { Oxygen, plasma } \\
\text { exchange }\end{array}$ & Death & 2 & Bilateral interstitial pulmonary infiltrates & $\begin{array}{l}\text { Carcinoma emboli in perivascular Iymphatic } \\
\text { vessels }\end{array}$ & $\begin{array}{l}\text { Gastric signet-ring cell } \\
\text { carcinoma }\end{array}$ \\
\hline 18 & Gainza et al. (19) & 34 & M & Cough, back pain & + & N/A & N/A & $\begin{array}{l}\text { Oxygen, plasma } \\
\text { exchange }\end{array}$ & Death & 12 & $\begin{array}{l}\text { Bilateral intersstitial pulmonary infiltrates, } \\
\text { infracentrimetric mediastinal and } \\
\text { retroperitoneal lymphadenopathies }\end{array}$ & $\mathrm{N} / \mathrm{A}$ & $\begin{array}{l}\text { Gastric signet-ring cell } \\
\text { carcinoma }\end{array}$ \\
\hline 19 & Gainza et al. (19) & 24 & $\mathrm{~F}$ & $\begin{array}{l}\text { Back pain, nausea, } \\
\text { vomiting }\end{array}$ & + & $\mathrm{N} / \mathrm{A}$ & Autopsy & Oxygen & Death & 2 & Bilateral interstitial pulmonary infiltrates & $\begin{array}{l}\text { Blood vessels with eccentric intimal fibrosis, } \\
\text { intravascular fibrin thrombi, and recanalization } \\
\text { and intraluminal emboli of neoplastic cells }\end{array}$ & $\begin{array}{l}\text { Poorly differentiated gastric } \\
\text { adenocarcinoma }\end{array}$ \\
\hline $\begin{array}{l}\text { Our } \\
\text { case }\end{array}$ & N/A & 62 & M & $\begin{array}{l}\text { Dyspnea, } \\
\text { hemoptysis }\end{array}$ & + & N/A & N/A & $\begin{array}{l}\text { Oxygen, anticoagulation, } \\
\text { antibiotic, steroid }\end{array}$ & Death & 3 & $\begin{array}{l}\text { New frosted glass-like shadow around } \\
\text { terminal pulmonary vessel, no arterial } \\
\text { embolization }\end{array}$ & N/A & $\begin{array}{l}\text { Hepatocellular carcinoma } \\
\text { and gastric signet-ring cell } \\
\text { carcinoma }\end{array}$ \\
\hline
\end{tabular}


as HCC and gastric signet-ring cell carcinoma, has been rarely reported. Since the most common original site of PTTM was the stomach, we queried the term "PTTM" and "gastric" on Pubmed.gov database in June of 2020 and received 48 results. We have reviewed 19 reported cases of PTTM caused by gastric carcinoma, except in our case (4-19) (Table 2).

According to our summary, the median survival time after oxygen supplementation was 18 days in PTTM patients caused by gastric carcinoma, which is longer than 9 days, as reported by Uruga et al. (3). However, our patient with both HCC and gastric signet-ring cell carcinoma showed a poorer prognosis, with a survival time of only 3 days (very poor compared to the average level). As tumor embolism, multiple microthrombi, and intimal myofibroblast proliferation in the pulmonary arteries and arterioles are among its histopathological characteristics $(1,2)$, multiple tumors might increase the tumor burden, resulting in more tumor embolism, resulting in faster progression.

Respiratory discomfort is the main symptom of PTTM. Of the 19 patients, 15 (79\%) displayed symptoms of respiratory discomfort. In addition, 13 had dyspnea, 9 had cough, 2 had chest pain, 1 had hemoptysis, and 2 had no respiratory difficulties. Moreover, 17 (89\%) manifested respiratory failure, leading to pulmonary arterial hypertension and right-sided heart failure. Nearly half of these cases showed severe pulmonary arterial hypertension, which was $54 \mathrm{mmHg}$ on average (9 cases). The clinical manifestations of PTTM depend on the severity of the PH. The degree of pulmonary arteries stenosis is diverse from each other, and it is suggested that PH in PTTM occurs in selected cases with widespread pulmonary lesions with severe smaller arteries stenosis (20).

Abnormal pulmonary imaging was reported in 12 (63\%) cases with the appearance of septal thickening, groundglass opacities, small nodules, pleural effusion, and a treein-bud pattern. Ground-glass opacification may reflect the tumor infiltration of the alveolar septae (21). Nodules are generally seen in a centrilobular distribution and are most likely to result from the hematogenous spread of malignancy through the pulmonary arterioles. The histologic correlation of septal thickening is known as the engorgement of lymphatic channels (22). Therefore, there are no specific imaging findings directly suggesting tumor embolism or pulmonary embolism. Our case shows a new frosted glass-like shadow around the terminal pulmonary vessel in a short time with no arterial embolization, which is highly considered in the presence of both HCC and gastric signet-ring cell carcinoma.

All patients with respiratory failure were administered oxygen, and additional treatments included anticoagulation in three cases, antibiotics in three cases, chemotherapy in three cases, steroids in two cases, plasma exchange in two cases, and imatinib in one case. No effective therapeutic options have been established for PTTM. Under the treatment, the survival time was longer than expected with the natural progression of PTTM. Among the important factors leading to a longer survival may be that the treatment regimen results in improvement in pulmonary pressures and/or cardiac output, in addition to treatment of the malignancy (23). The shortest period between the commencement of treatment for respiratory failure and death was 1 day, the longest was 210 days, and the average was 18 days. Case 2, who was treated with imatinib, had the longest survival time of 210 days. Imatinib, a plateletderived growth factor (PDGF) receptor inhibitor, may play a role in reducing the vascular remodeling that promulgates $\mathrm{PH}$. Although it has shown promise by prolonging survival time in some cases, its role may be limited to various factors such as the type of primary malignancy; any further use of imatinib should be studied more extensively (24). Bevacizumab, a vascular endothelial growth factor (VEGF) receptor inhibitor, has also been used in one case in conjunction with S-1 chemotherapy and imatinib, where the patient experienced a survival of 12 months after a diagnosis of PTTM (25).

\section{Conclusions}

PTTM should be considered in patients with cancer who progress to rapid respiratory failure and $\mathrm{PH}$, especially in patients with multiple tumors whose condition is more likely to progress quickly.

\section{Acknowledgments}

Funding: None.

\section{Footnote}

Reporting Checklist: The authors have completed the CARE reporting checklist. Available at http://dx.doi.org/10.21037/ tcr-20-3107

Conflicts of Interest: All authors have completed the ICMJE uniform disclosure form (available at http://dx.doi. 
org/10.21037/tcr-20-3107). The authors have no conflicts of interest to declare.

Ethical Statement: The authors are accountable for all aspects of the work in ensuring that questions related to the accuracy or integrity of any part of the work are appropriately investigated and resolved. All procedures performed in studies involving human participants were in accordance with the ethical standards of the institutional and/or national research committee(s) and with the Helsinki Declaration (as revised in 2013). Written informed consent was obtained from the patient.

Open Access Statement: This is an Open Access article distributed in accordance with the Creative Commons Attribution-NonCommercial-NoDerivs 4.0 International License (CC BY-NC-ND 4.0), which permits the noncommercial replication and distribution of the article with the strict proviso that no changes or edits are made and the original work is properly cited (including links to both the formal publication through the relevant DOI and the license). See: https://creativecommons.org/licenses/by-nc-nd/4.0/.

\section{References}

1. von Herbay A, Illes A, Waldherr R, et al. Pulmonary tumor thrombotic microangiopathy with pulmonary hypertension. Cancer 1990;66:587-92.

2. Chinen, K, Tokuda, Y, Fujiwara, M, et al. Pulmonary tumor thrombotic microangiopathy in patients with gastric carcinoma: an analysis of 6 autopsy cases and review of the literature. Pathol Res Pract 2010;206:682-9.

3. Uruga H, Fujii T, Kurosaki A, et al. Pulmonary tumor thrombotic microangiopathy: a clinical analysis of 30 autopsy cases. Intern Med 2013;52:1317-23.

4. Cui N, Wang L, Zhao J. Pulmonary tumour thrombotic microangiopathy presented as gastric signet ring cell carcinoma: a case report. J Int Med Res 2020;48:300060520910884.

5. Kubota K, Shinozaki T, Imai Y, et al. Imatinib dramatically alleviates pulmonary tumour thrombotic microangiopathy induced by gastric cancer. BMJ Case Rep 2017;2017:bcr2017221032.

6. Mandaliya R, Farhat S, Uprety D, et al. Occult gastric cancer presenting as hypoxia from pulmonary tumor thrombotic microangiopathy. J Gastric Cancer 2014;14:142-6.

7. Tateishi A, Nakashima K, Hoshi K, et al. Pulmonary tumor thrombotic microangiopathy mimicking inhalation lung injury. Intern Med 2019;58:1311-4.

8. Belhassine M, Papakrivopoulou E, Venet C, et al. Gastric adenocarcinoma revealed by atypical pulmonary lymphangitic carcinomatosis. J Gastrointest Oncol 2018;9:1207-12.

9. Yokomine T, Hirakawa H, Ozawa E, et al. Pulmonary thrombotic microangiopathy caused by gastric carcinoma. J Clin Pathol 2010;63:367-9.

10. Ho AL, Szulakowski P, Mohamid WH. The diagnostic challenge of pulmonary tumour thrombotic microangiopathy as a presentation for metastatic gastric cancer: a case report and review of the literature. BMC Cancer 2015;15:450. Erratum in: BMC Cancer. 2015 Aug 26;15:600. doi: 10.1186/s12885-015-1601-6.

11. Kuwabara H, Yoshida S, Takasu, T, et al. Pulmonary tumor thrombotic microangiopathy caused by gastric cancer. Ann Thorac Med 2012;7:168-9.

12. Endicott-Yazdani T, Ghazi A, Armstrong D, et al. Fatal pulmonary tumor thrombotic microangiopathy caused by undiagnosed metastatic gastric adenocarcinoma. Proc (Bayl Univ Med Cent) 2015;28:482-3.

13. Rudkovskaia AA, Lo YC, Brady V, et al. A 49-year-old man with subacute respiratory failure and interstitial lung opacities. Am J Case Rep 2017;18:941-4.

14. Chinen K, Kazumoto T, Ohkura Y, et al. Pulmonary tumor thrombotic microangiopathy caused by a gastric carcinoma expressing vascular endothelial growth factor and tissue factor. Pathol Int 2005;55:27-31.

15. Sato Y, Marutsuka K, Asada Y, et al. Pulmonary tumor thrombotic microangiopathy. Pathol Int 1995;45:436-40.

16. McAnearney S, Drain M. A case of pulmonary tumour thrombotic microangiopathy. Respir Med Case Rep 2015;16:7-10.

17. Seol SH, Park BM, Jin HY, et al. Fatal acute right heart failure in gastric cancer patients. Heart Views 2013;14:179-81.

18. Keenan NG, Nicholson AG, Oldershaw PJ. Fatal acute pulmonary hypertension caused by pulmonary tumour thrombotic microangiopathy. Int J Cardiol 2008;124:e11-3.

19. Gainza E, Fernandez S, Martinez D, et al. Pulmonary tumor thrombotic microangiopathy: report of 3 cases and review of the literature. Medicine (Baltimore) 2014;93:359-63.

20. Okubo Y, Wakayama M, Kitahara K, et al. Pulmonary tumor thrombotic microangiopathy induced by gastric carcinoma: morphometric and immunohistochemical analysis of six autopsy cases. Diagn Pathol 2011;6:27. 
21. Collins J, Stern EJ. Ground-glass opacity at CT: the ABCs. AJR Am J Roentgenol 1997;169:355-67.

22. Godbole R, Saggar R, Zider A, et al. Insights on pulmonary tumor thrombotic microangiopathy: a sevenpatient case series. Pulm Circ 2017;7:813-20.

23. Godbole RH, Saggar R, Kamangar N. Pulmonary tumor thrombotic microangiopathy: a systematic review. Pulm
Circ 2019;9:2045894019851000.

24. Price LC, Wells AU, Wort SJ. Pulmonary tumour thrombotic microangiopathy. Curr Opin Pulm Med 2016;22:421-8.

25. Higo K, Kubota K, Takeda A, et al. Successful antemortem diagnosis and treatment of pulmonary tumor thrombotic microangiopathy. Intern Med 2014;53:2595-9.
Cite this article as: Shen L, Yang L, Jiang H, Mo T, Fan M. Pulmonary tumor thrombotic microangiopathy of patient with both hepatocellular carcinoma and gastric signet-ring cell carcinoma: a case report and review of literature. Transl Cancer Res 2021;10(4):1930-1940. doi: 10.21037/tcr-20-3107 